\title{
HUBUNGAN IBU HAMIL PEROKOK PASIF DENGAN BERAT BAYI LAHIR RENDAH (BBLR) PADA BAYI BARU LAHIR DI KABUPATEN PRINGSEWU LAMPUNG
}

\section{RELATIONSHIP OF PREGNANT WOMEN WITH PASSIVE SMOKER WITH LOW BIRTH WEIGHT (LBW) ON NEWBORN BABY IN PRINGSEWU REGENCY LAMPUNG}

\author{
Kartika Setia Rini ${ }^{1}$, Istikomah ${ }^{2}$ \\ ${ }^{1,2}$ Program Studi Diploma III Kebidanan STIkes Muhammadiyah Pringsewu
}

\begin{abstract}
ABSTRAK
Indonesia merupakan negara dengan Angka Kematian Bayi (AKB) yang masih tergolong tinggi meski mengalami penurunan tiap tahunnya. Jumlah AKB yang tinggi salah satunya disebabkan karena Berat Bayi Lahir Rendah (BBLR). Bayi dengan BBLR adalah keadaan bayi yang baru dilahirkan memiliki berat badan kurang dari 2500 gram. Kejadian BBLR dipengaruhi oleh banyak faktor, salah satunya adalah ibu perokok pasif. Asap rokok yang di hirup oleh wanita hamil merupakan salah satu yang menyebabkan BBLR pada bayi yang akan dilahirkannya. Pencegahan bayi dengan BBLR dapat diatasi dengan kerjasama dari berbagai pihak yang berada dekat dengan ibu hamil untuk tidak merokok. Tujuan dari penelitian ini adalah untuk menganalisis hubungan perokok pasif dengan kejadian BBLR pada bayi baru lahir .Desain penelitian yang digunakan adalah analitik dengan pendekatan case control . populasi penelitian ini adalah seluruh bayi baru lahir yang ada di BPM Margiati tahun 2011-2014 dengan jumlah 310 bayi. Jumlah sampel yang digunakan yaitu 44 bayi. Alat pengumpulan data dengan menggunakan lembar observasi. Analisis data yang digunakan adalah analisis univariabel dan bivariabel.Berdasarkan hasil uji statistik menggunakan uji Chi Square $\left(x^{2}\right)$ dengan Confidence Interval 95\% diperoleh nilaip-value $<0.05$. Dapat disimpulkan bahwa tidak ada hubungan antara ibu hamil perokok pasif dengan kejadian bayi BBLR.
\end{abstract}

Kata kunci: Perokok pasif, BBLR

\begin{abstract}
Indonesia is the country with the one of high numeral infant death country. Baby Mortality Rate (BMR) at Indonesian still tall rank even experience decrease per year. Apparently Baby Mortality Rate which high one of it is caused because Low Birth Weight (LBW). LBW is situation where baby a new one bearing to have body weight less than 2500 grams. Baby's with LBW instance regarded by a lot of factor, one of it is passive smoker mother. Smoking smoke that at breathes in by pregnancy woman constitute one of causative LBW on baby who will be borne it. LBW can be prevented by collaboration of a variety party which lies close to pregnancy mother for doesn't smoke. The purpose of this study was to analyze the relationship between passive smoking with LBW in new born baby. The studies design is analytic with case control approach. Population is all newborn baby that is at Margiati's midwife private practice year 2012-2015 by total 310 babies which take with 44 samples. Tool of data's collecting by use of observation sheet. Analysis use the analysis univariable and bivariable. Based on the statistical test using Chi Square test with $95 \%$ Confidence Interval obtained $\rho$-value of $<0.05$. It can be concluded that there is no association between passive smoking pregnant women with the incidence of LBW infants.
\end{abstract}

Keywords: Passive, smoker, low birth weight 


\section{PENDAHULUAN}

Menurut data Survey Demografi Kesehatan Indonesia (SDKI) 2012 empat Negara termasuk Indonesia diantara Filipina, Laos dan Kamboja termasuk negara dengan angka kematian bayi tinggi. Sedangkan. Dari 10 negara anggota ASEAN, tidak ada yang masuk dalam kelompok angka kematian bayi sangat tinggi (>100 per 1.000 kelahiran hidup). ${ }^{1}$ Kesimpulannya, dibandingkan Negara Myanmar, Indonesia merupakan Negara dengan Angka Kematian Bayi sedang.

Angka Kematian Bayi di Negara Indonesia terus menurun tiap tahun, namun tingkat kematian bayi di Indonesia masih tergolong tinggi jika dibandingkan dengan negara-negara anggota ASEAN, yaitu 4,2 kali lebih tinggi dari Malaysia, 1,2 kali lebih tinggi dari Filipina, dan 2,2 kali lebih tinggi dari Thailand. ${ }^{2}$ Berdasarkan data di atas, $\mathrm{AKB}$ di Indonesia masih tergolong tinggi meski mengalami penurunan tiap tahunnya.

Data tahun 2013, lebih dari 23 juta bayi $(17,5 \%$ dari seluruh kelahiran bayi di dunia) setiap tahun merupakan bayi BBLR dan $(92,8 \%)$ diantaranya lahir di negara berkembang. Kejadian BBLR di Negara berkembang adalah $(18,4 \%)$ atau 2 kali lebih besar dibandingkan dengan di Negara maju $(9 \%)^{2}$ Jumlah AKB yang tinggi salah satunya disebabkan karena BBLR.
Bayi dengan BBLR adalah keadaan dimana bayi yang baru dilahirkan memiliki berat badan kurang dari 2500 gram. Akibat dari BBLR adalah dapat menyebabkan gangguan neurologis, keterlambatan pertumbuhan, perkembangan kognitif, berisiko menderita penyakit-penyakit kronik seperti penyakit kardiovaskular, hipertensi, dan penurunan kecerdasan. Khusus bayi perempuan dengan BBLR, nanti juga cenderung melahirkan bayi dengan BBLR. ${ }^{3}$

Kejadian BBLR dipengaruhi oleh beberapa faktor seperti umur, paritas, jarak kehamilan, antenatal care, keadaan sosial ekonomi, ibu perokok pasif, dan riwayat penyakit ibu. ${ }^{4}$ Jadi, kejadian BBLR dipengaruhi oleh banyak faktor, salah satunya adalah ibu perokok pasif.

Hampir setiap saat dapat disaksikan dan dijumpai orang yang sedang merokok di sebelah ibu yang sedang menggendong bayi sekalipun, orang tersebut tetap tenang menghembuskan asap rokoknya. Selama beberapa tahun terakhir, para ilmuwan telah membuktikan bahwa zat-zat kimia yang dikandung asap rokok dapat memengaruhi orang-orang yang tidak merokok di sekitarnya. Orang-orang yang tidak merokok, namun menjadi korban perokok karena turut mengisap asap sampingan (di samping asap utama yang di 
hembuskan baik oleh perokok). ${ }^{5}$ Asap rokok yang di hirup oleh wanita hamil merupakan salah satu yang menyebabkan BBLR pada bayi yang akan dilahirkannya.

Salah satu cara pencegahan terjadinya kelahiran BBLR yaitu diperlukan kerjasama dari berbagai pihak baik keluarga, teman-teman kerja dan orang-orang disekitar ibu hamil untuk tidak merokok. Serta membuat peraturan yang lebih jelas mengenai tempat-tempat mana saja yang boleh dan tidak boleh merokok, bila dilingkungan sekitar banyak yang merokok dan tidak bisa dilarang, pakailah masker atau jauhi orang-orang yang merokok. ${ }^{5}$

Hasil survei yang dilakukan di dua Bidan Praktik Mandiri (BPM) kabupaten Pringsewu pada periode 4 tahun diperoleh hasil kejadian BBLR lebih banyak di BPM Margiati dibandingkan BPM Fika Saumi. Kejadian BBLR di BPM Margiati yaitu dengan 24 orang atau 7,74\% dari 310 bayi baru lahir, sedangkan di BPM Fika Saumi yaitu sejumlah 5 orang atau 5,43\% dari 57 bayi baru lahir. ${ }^{6,7}$ Berdasarkan masalah tersebut, maka peneliti tertarik untuk melakukan penelitian tentang "Hubungan Ibu Hamil Perokok Pasif dengan BBLR pada bayi baru lahir". Tujuan penelitian ini adalah untuk menganalisis hubungan ibu hamil perokok pasif dengan kejadian BBLR pada byi baru lahir.

\section{METODE}

Jenis penelitian ini adalah Analitik dengan rancangan penelitian case control. Dalam penelitian ini, variabel terikat yaitu BBLR dengan variabel bebas yaitu perokok pasif. Penghitungan Besar sampel minimal menggunakan program Epi Info versi 3,5,3 dengan berdasarkan rumus case control dengan hasil adalah 22 ibu hamil yang bayinya mengalami BBLR dan $22 \mathrm{ibu}$ hamil yang bayinya tidak BBLR sehingga besar sampel minimal pada penelitian ini adalah 44 orang. Kriteria inklusi penelitian ini yaitu ibu bersalin dengan kejadian BBLR dan ibu bersalin yang terpapar asap rokok 1-10 batang perhari. Penelitian dilakukakan di BPM Margiati Kabupaten Pringsewu Lampung tahun 2016.

\section{HASIL DAN PEMBAHASAN}

Analisis yang dilakukan dalam penelitian ini adalah analisis univariat dan bivariat yang dilakukan untuk mengetahui hubungan antara ibu hamil perokok pasif dengan BBLR. Hasil analisis univariabel disajikan dalam tabel distribusi frekuensi di bawah ini: 
Tabel 1 Distribusi Frekuensi Ibu Perokok Pasif dengan BBLR di BPM Margiati Gadingrejo

\begin{tabular}{rlcc}
\hline Kategori & $\begin{array}{c}\text { Frekuensi } \\
(\mathbf{n})\end{array}$ & $\begin{array}{c}\text { Proporsi } \\
(\mathbf{\%})\end{array}$ \\
\hline 1. & BBLR & 24 & $52,17 \%$ \\
- & BBLR & 24 & $47,83 \%$ \\
- & Tidak BBLR & 24 & \\
\hline 2. & Perokok pasif & & \\
- & Perokok pasif & 28 & $58,33 \%$ \\
- & Bukan & 20 & $41,67 \%$ \\
& perokok pasif & & \\
\hline
\end{tabular}

Berdasarkan tabel 1 dapat dilihat bahwa proporsi ibu hamil perokok pasif lebih tinggi dibandingkan ibu hamil yang bukan perokok pasif. Sedangkan proporsi BBLR lebih besar dibandingkan proporsi yang tidak BBLR.

\section{Analisis bivariabel}

Analisis bivariabel dilakukan untuk mengetahui ibu hamil perokok pasif dengan BBLR. Analisis bivariabel disajikan dalam tabel silang $2 \times 2$ di bawah ini:

Tabel 2 Analisis Bivariabel Hubungan Ibu perokok pasif dengan BBLR pada bayi baru lahir di BPM Margiati Gadingrejo

\begin{tabular}{|c|c|c|c|c|c|c|c|c|}
\hline \multirow{3}{*}{$\begin{array}{l}\text { Perokok } \\
\text { Pasif }\end{array}$} & \multicolumn{4}{|c|}{ BBLR } & \multirow{3}{*}{ OR } & \multirow{3}{*}{$\chi^{2}$} & \multirow{3}{*}{ CI $95 \%$} & \multirow{3}{*}{$\begin{array}{l}P \\
\text { value }\end{array}$} \\
\hline & \multicolumn{2}{|c|}{$\mathbf{Y a}$} & \multicolumn{2}{|c|}{ Tidak } & & & & \\
\hline & $\mathrm{N}$ & $\%$ & $\mathbf{N}$ & $\%$ & & & & \\
\hline $\begin{array}{l}\text { - Peroko } \\
\text { k pasif }\end{array}$ & 16 & 66,67 & 12 & 50 & 2 & $\begin{array}{l}0.77 \\
14\end{array}$ & $\begin{array}{l}0.6229- \\
6.421\end{array}$ & 0.3798 \\
\hline $\begin{array}{l}\text { Bukan } \\
\text { peroko } \\
\mathrm{k} \text { pasif }\end{array}$ & 8 & 33,33 & 12 & 50 & & & & \\
\hline $\mathbf{N}$ & 24 & 100 & 24 & 100 & & & & \\
\hline
\end{tabular}

Berdasarkan hasil uji statistik pada tabel 2 Chi Square nilai $\rho=0.3798$ menunjukkan bahwa tidak ada hubungan antara ibu hamil perokok pasif dengan BBLR. Variabel BBLR dengan tidak BBLR memiliki CI (95\%) berada antara 0.6229-6.421 yang artinya variabel ibu perokok pasif tidak ada hubungan dengan BBLR. Nilai OR $=2$ menunjukkan bahwa Ibu perokok pasif memiliki risiko 2 kali lebih besar untuk mengalami BBLR dibandingkan dengan tidak mengalami BBLR pada kelompok bukan perokok pasif.

Hasil penelitian ini sama dengan penelitian yang dilakukan oleh Sutrisno dkk tahun 2013 di RSD Kalista Jember mengenai hubungan ibu hamil sebagai perokok pasif dengan berat badan bayi baru lahir di RSD Kalista Jember menggunakan rancangan cross sectional mempunyai hubungan lemah tapi pasti antara ibu hamil sebagai perokok pasif dengan berat badan bayi baru lahir di RSD Kalisat Kabupaten Jember periode AprilMei 2013 dan memiliki resiko 2,4 kali lebih sering untuk terjadinya bayi berat lahir rendah (BBLR). Dari hasil penelitian diperoleh hasil bahwa mayoritas ibu bersalin selama hamil menjadi perokok pasif $(66,2 \%)$. Merokok sudah menjadi kebiasaan penduduk kalisat baik remaja maupun orang tua. Kebiasaan perokok aktif untuk merokok di dalam rumah dan 
di tempat-tempat umum masih cukup banyak, sehingga meningkatkan jumlah perokok pasif penduduk kalisat terutama para ibu hamil. Oleh karena itulah, akibat meningkatnya jumlah perokok pasif khususnya ibu hamil maka dapat meningkatkan jumlah ibu yang melahirkan bayi prematur dengan berat badan lahir rendah.

Hasil penelitian ini berbeda dengan hasil penelitian Ramadhan di Badan Layanan Umum Daerah Rumah Sakit Umum Meuraxa Kota Banda Aceh 2012 bahwa dari bahwa dari 4 responden yang perokok pasif berat di dapatkan $3(75 \%)$ ibu mengalami kejadian BBLR (BayiBerat Lahir Rendah), dari 26 responden yang perokok pasif ringan di dapatkan 9 $(34,6 \%)$ ibumelahirkan bayi berat badan normal, sedangkan dari 15 responden yang tidak terpapar dengan asap rokok didapatkan 15 (100\%), ibu melahirkan dengan bayi berat badan normal (tidak mengalami kejadian BBLR). Dari hasil uji Statistik, Chi -square diperoleh nilai kemaknaan $p=0,004(p \leq 0,05)$, maka dapat disimpulkan bahwa terdapat hubungan yang bermakna antara ibu hamil perokok pasif dengan kejadian Berat Badan Lahir Rendah (BBLR). Dari hasil uji Statistik, Chi-square diperoleh nilai kemaknaan $p=0,004(p \leq 0,05)$, maka dapat disimpulkan bahwa terdapat hubunganyang bermakna antara ibu perokok pasif dengan kejadian Berat Badan Lahir Rendah (BBLR). Sesuai dengan penelitian yang dilakukan oleh Irnawati tahun 2010 dalam penelitiannya kasus kontrol dengan judul "Risiko Terjadinya Bayi Berat Lahir Rendah Pada Ibu Hamil Perokok Pasif di Kota Banda Aceh". 8 hasil penelitian menunjukkan ibu hamil yang terpapar asap rokok 1 sampai 10 batang per hari selama kehamilannya akan berisiko 2,47 kali lebih tinggi untuk melahirkan BBLR. ${ }^{9}$ Secara singkat dapat dijelaskan bahwa radikal bebas yang terkandung dalam asap rokok dapat menyebabkan kerusakan endotel, peningkatan vasokonstriktor, dan penurunan vasodilator sehingga terjadi PPOK (Penyakit Paru Obstruktif Kronik), selain itu radikal bebas juga dapat menyebabkan defisiensi asam folat.Sedangkan nikotin yang juga terkandung dalam asap rokok dapat menyebabkan vasokonstriksi pembuluh darah yang dapat menyebabkan hipertensi sehingga terjadi penurunan suplai makanan dan oksigen fetus. Akibatnya secara tidak langsung, hipertensi, PPOK, dan defisiensi asam folat akan menimbulkan gangguan pertumbuhan fetus yang pada akhirnya akan dapat mempengaruhi BBL. ${ }^{10,}$

Kebiasaan yang dilakukan oleh suami seperti merokok sangat berbahaya bagi pertumbuhan janin pada ibu hamil. Hal ini dikarenakan kadar nikotin yang 
cukup tinggi yang ditimbulkan oleh asap rokok. Dampak sederhana yang ditimbulkan adalah susah memiliki keturunan, kelahiran tidak normal, dan kejadian BBLR. hal ini menunjukkan bahwa ada hubungan antara kejadian BBLR dengan kebiasaan merokok yang dilakukan oleh suami maupun ibu hamil. ${ }^{11}$ Berdasarkan hasil penelitian, presentase bayi yang lahir dengan BBLR lebih besar presentasenya pada ibu hamil perokok pasif dibandingkan dengan Bayi Baru Lahir Normal (BBLN) pada ibu hamil perokok pasif yaitu $(81,2 \%){ }^{12}$

Seringnya ibu hamil terpapar asap rokok membuat kandungan yang ada dalam asap rokok masuk ke dalam pembuluh darah ibu kemudian menyumbat pembuluh darah dan menghambat proses masuknya nutrisi dari ibu ke janin, selain itu juga anemia dapat pula menjadi penyebab terjadinya BBLR karena pada ibu hamil yang memiliki anemia di dalam darahnya kekurangan oksigen yang berperan penting dalam transportasi zat makanan ke seluruh tubuh terutama ke janin. Hal ini menyebabkan nutrisi dari ibu ke janin berkurang dan dapat menyebabkan penurunan berat badan bayi selama di dalam kandungan yang kemudian terjadilah BBLR. ${ }^{13}$

Secara praktis didapatkan hasil bahwa peluang ibu hamil perokok pasif memiliki risiko 2 kali lebih besar mengalami BBLR dibandingkan dengan ibu hamil yang bukan perokok pasif. Diduga, kejadian BBLR dapat terjadi dikarenakan banyak faktor seperti: genetik (faktor gen, interaksi lingkungan, berat badan ayah, jenis kelamin), kecukupan gizi (nutrisi ibu ketika hamil, kecukupan protein dan energi, kekurangan nutrisi), karakteristik dan berat ibu (berat ibu ketika hamil, paritas, jarak kelahiran), penyakit (infeksi di masyarakat seperti malaria, anaemia, syphilis, rubella), komplikasi kehamilan (eklamsi, infeksi ketika melahirkan), gaya hidup ibu (merokok dan mengkonsumsi alkohol) dan lingkungan (polusi, faktor sosial ekonomi). ${ }^{14,15,16}$ sehingga walaupun tidak ada satupun anggota keluarga yang perokok aktif, tetapi kemungkinan salah satu faktor di atas dapat menyebabkan BBLR.

\section{SIMPULAN}

Berdasarkan hasil penelitian dapat disimpulkan bahwa tidak terdapat hubungan antara ibu hamil perokok pasif dengan BBLR pada bayi baru lahir. Namun demikian, nilai perokok pasif berisiko 2 kali lebih besar antara kelompok ibu yang tidak terpapar asap rokok.

\section{SARAN}

Saran bagi ibu hamil adalah agar tidak terlalu sering berdekatan dengan perokok 
aktif, anggota keluarga yang tinggal serumah agar mengetahui bahaya merokok dan paparan asap rokok agar dapat diterapkan dalam kehidupan sehari-hari.

\section{DAFTAR PUSTAKA}

1. Kementrian Kesehatan RI, BKKBN, BPS. 2013. Survey Demografi Kesehatan Indonesia tahun 2012. Jakarta

2. Kementerian Kesehatan RI. 2013. Profil Kesehatan Indonesia 2012. Jakarta.

3. Kasim F, Surachman T, Ruswandiani. 2011. Hubungan antara Karakteristik Ibu Hamil dengan Kejadian Bayi Berat Badan Lahir Rendah di Rumah Sakit Immanuel Bandung Tahun 2008. Jurnal Kedokteran Maranatha. Bandung

4. Maryanti D, Sujianti, Budiarti T, ( 2011), Buku Ajar Neonatus, Bayi Dan Balita. Jakarta:Trans Info media.

5. Nursaidah, Isroaini A. 2012. Hubungan Suami Perokok Dengan Terjadinya Bayi Berat Badan Lahir Rendah Di RSUD Sidoarjo Jenis Persalinan Dengan Skala Nyeri Involusi Uterus Masa Nifas Di RSUD Prof. Dr. Soekandar Mojosari Mojokerto. Jurnal Ilmiah Kesehatan Politeknik Kesehatan Majapahit. Vol 4 no.2. Mojokerto.

6. Laporan Registrasi BPM Margiati Kecamatan Gadingrejo Kabupaten Pringsewu. Provinsi Lampung 20122015.

7. Laporan Registrasi BPM Fika Saumi Kecamatan Gadingrejo Kabupaten Pringsewu. Provinsi Lampung 20122015.
8. Irnawati, Mohammad Hakim, Tanjung Wibowo, (2011), "Ibu Hamil perokok pasif sebagai factor resiko bayi berat lahir rendah". JURNAL GIZI KLINIK INDONESIA.Vol. 8, No. 2, Oktober 2011: 54-5

9. Ramadhan, Nurlaila. 2012. Hubungan ibu hamil perokok pasif dengan kejadian bayi berat lahir renda di badan layanan umum daerah RSU Meuraxa Banda Aceh. Jurnal Ilmiah STIKES U'Budiyah Vo. 1 no. 2

10. Sutrisno, 2013. Hubungan Ibu Hamil Sebagai Perokok pasif Dengan Berat Badan Bayi Baru Lahir di RSD Kalisat Kabupaten Jember.

11. Aryani, Ratna,2010. Kesehatan Remaja. Jakarta: Salemba Medika

12. Rufaridah anne. 2011. Pengaruh perokok pasif terhadap plasenta, berat badan lahir, apgar score bayi baru lahir pada ibu hamil di Kabupaten. Padang. Tesis. Ilmu Biomedik Universitas Andalas.

13. Irnawati. (2007). "Resiko terjadinya Bayi Berat Lahir Rendah pada ibu hamil perokok pasif di Kota Banda Aceh Propinsi Nanggroe Aceh Darussalam”. Tesis. Universitas Gajah Mada

14. Saifuddin A, (2010), Buku Panduan Praktis Pelayanan Kesehatan Maternal dan Neonatal. Jakarta:PT. Bina Pustaka.

15. Swantantika D, (2013), Bahaya Asap Rokok Untuk Janin Anda.http://id.theasianparent.com/bah aya-asap-rokok-untuk-janin-anda/\#. Diakses pada tanggal 6 maret 2015

16. Sofian A, (2012), Sinopsis Obstetri. Pekanbaru:Penerbit Buku Kedokteran 